\title{
Impacts of COVID-19 on the Labour Market - Evidence from the Czech Republic
}

\author{
Martina HEDVIČÁKOVÁ ${ }^{*}$ and Zuzana KOZUBÍKOVÁ \\ 1 University of Hradec Králové, Hradec Králové, Czech Republic; martina.hedvicakova@uhk.cz. \\ 2 University of Žilina, Žilina, Slovak Republic; zuko@frcatel.fri.uniza.sk \\ * Corresponding author: martina.hedvicakova@uhk.cz
}

\begin{abstract}
The current pandemic has far-reaching consequences for people's lives, employment and family life; has also changed the economic environment. The Covid-19 pandemic had, among other things, significant effects on the labour market, which has undergone significant changes. Thanks to the support of the Czech government and its program, the unemployment rate in 2020 remained so far at $3.51 \%$, which is the lowest unemployment rate of all EU countries. The labour market also opens up space for a more significant implementation of the Industry 4.0 concept, which can increase the competitiveness of companies. The aim of the article is to analyse the dynamic development of basic values observed in the labour market (employment, unemployment, wage developments, etc.) in individual quarters since 2018. Furthermore, the Czech government's employment support programs and the main changes that may occur as a result of the Covid19 pandemic were presented. The paper presents a multilevel analysis of given condition, as it also takes into account the framework of global changes, which we became part of before the arrival of Covid-19. Without these changes, it is not possible to move advance in with the Industry 4.0 initiative.
\end{abstract}

Keywords: unemployment; Industry 4.0; economy; labour market; changes

\section{JEL Classification: E24; J21; O11}

\section{Introduction}

The labour market has experienced significant changes related to the Covid-19 pandemic since 2020. These changes had a significant impact on all economic sectors, including employers and employees. The government of the Czech Republic had to deal with the support of the labour market and the employees themselves. The impacts of Covid-19 were in all areas but to varying degrees.

COVID-19 focused on this topic. People are affected in the context of the Covid-19 pandemic differently depending on their social class or caste, gender and age, and the country in which they live (van Barneveld et al., 2020).

From a macroeconomic point of view, the pandemic will primarily have effects on the gross domestic product (GDP) and the labour market.

As the authors state (Sakshaug et al., 2020): “The COVID-19 pandemic and associated government lockdown restrictions have fuelled a high demand for survey data on how individuals and establishments are coping with the restrictions. However, the pandemic has 
also dramatically affected surveys themselves, forcing research institutes to adapt their fieldwork operations to the uncertain and evolving conditions."

The COVID-19 pandemic and subsequent lockdowns with various national measures have had a significant impact on labour mobility around the world. These changes in the labour market also lead to changes in labour relations (Reichelt et al., 2020).

Given the macroeconomic impact of the Covid-19 pandemic, it is also necessary to analyse the impact on the Industry 4.0 initiative. Industry 4.0 is gaining in relevance and importance due to the ongoing pandemic. Due to the lack of jobs in the labour market, shortages of workers due to quarantine reasons, uncertainty in demand, various restrictive measures of the government, etc., Industry 4.0 is gaining huge potential.

From the position of the global economy, the formation of Industry 4.0 is not only a tool for achieving strategic goals in international marketing and profit-making by certain states but a means for solving global human problems and achieving global economic progress and social well-being (Sozinova, 2019).

With Industry 4.0, the necessary substitution of labour by capital can occur. However, this substitution must be made in such a way that there is no further rise in unemployment (Hedvicakova, 2018; Hedvičáková \& Král, 2019; Maresova et al., 2018; Svobodová \& Hedvičáková, 2015).

According to Ragulina (2019), the management of the development of Industry 4.0 should be carried out in light of the progress made in shaping the knowledge economy. The offered priorities and the developed logical scheme of development management of Industry 4.0 in modern economic systems, depending on the progress in the formation of the knowledge economy, takes this peculiarity into account and enables its best use for the economic system.

Different countries approach the Industry 4.0 initiative differently and also support it in different financial amounts. The biggest difference in the formation of Industry 4.0 is between developing and developed countries. Compared to developed countries, where the process of forming Industry 4.0 was started earlier and focused on marketing and social results, developing countries face institutional (absence of state policy of forming Industry 4.0) and financial obstacles and seek economic goals (Bogoviz et al., 2019; Král \& Hájek, 2018; Matějíček \& Marešová, 2020).

The current epoch we are just living is characterised by the development of advanced electronics and digital technologies. This is reflected by increasing productivity and dynamic economic growth in developed industrial countries (Kozubíková, 2016). How stated in Kucharčíková et al. (2015) the key role in this massive productivity increase belongs to human capital. In order for this to apply in the conditions of the knowledge society, new skills and competencies are also aimed at supporting innovation. It is innovations in production that accelerate the technological development of the industry.

From Kozubíková (2016) further follows that the labour market requires highly qualified individuals in these disrupted times. The workforce must be equipped with new skills and competencies. This is the only way to create the preconditions for increasing productivity and maintaining competitiveness. This underlines the need to build a quality education system. 


\section{Methodology}

The COVID-19 pandemic has caused a global health crisis that has rapidly transformed the economy and its consequences are visible in a huge labour market (Lee et al., 2020). In this article, we will deal with the consequences of a pandemic on the labour market in the Czech Republic. Create an ongoing pandemic is the current assessment of the labour market and especially its further development is affected by a high degree of uncertainty. The prediction of further development is even more uncertain and therefore we will analyse the year 2019 and 2020 in particular.

To better illustrate the effects of the pandemic on the labour market, the individual regions of the Czech Republic were also analysed.

The aims of the paper are to capture the dynamic development of basic values observed in the labour market (employment, wage developments etc.) in the Czech Republic due to the Covid-19 pandemic.

For the purposes of the article, primarily primary sources were used. Information about the labour market in the Czech Republic was drawn mainly from the Czech Statistical Office and the Ministry of Labour and Social Affairs. Information on programs supporting entrepreneurs and employees was drawn primarily from the Ministry of Industry and Trade of the Czech Republic. Knowledge from scientific articles and professional conferences was also used in the preparation of the paper.

\section{Results}

The following figure 1 shows the development of the share of unemployed persons in the Czech Republic for the period 2005-2020. The figure shows that the share of unemployed persons was the highest in 2014 when it reached 7.70\%. Since then, there has been a decline, which did not stop until 2019. In 2019, there was an excess of labour demand in the Czech Republic over labour supply. There was also an increase in average wages. In 2020, the share of the unemployed increased for the first time due to the onset of the Covid-19 pandemic. The share of the unemployed was 3.51\% in 2020. This percentage is Despite the ongoing pandemic after the natural rate of unemployment.

The general unemployment rate was 3.1\% in December 2020 in the Czech Republic. This is the lowest unemployment rate of all European Union countries. Despite rising slowly, the current level of unemployment is lower than the assigned level of unemployment. The graph shows that there was no significant increase in the number of unemployed due to the pandemic, and the Czech Republic maintains the lowest unemployment rate among EU countries. According to Eurostat, the unemployment rate in the Euro area is $8.3 \%$ and in the EU-27 the unemployment rate is 7.5\% in December 2020 (see Figure 2).

Now we will focus in detail on the labour market in the Czech Republic in individual quarters from 2018-2020. Figure 3 shows that employment grew in 2018 and the Czech Republic amounted to economic growth. In 2019, there was already a slight decline and slowdown in economic growth before the Covid-19 pandemic began. The first restrictive measures related to Covid-19 were at the end of the first quarter of 2020 and manifested themselves mainly in the second quarter when it was the largest. The decrease in the number 
of employees in thousands and the associated increase in the number of unemployed responded to this. During the summer months and the beginning of autumn, there was a slight recovery, but in the last quarter, there were again increased restrictive measures and rising unemployment.

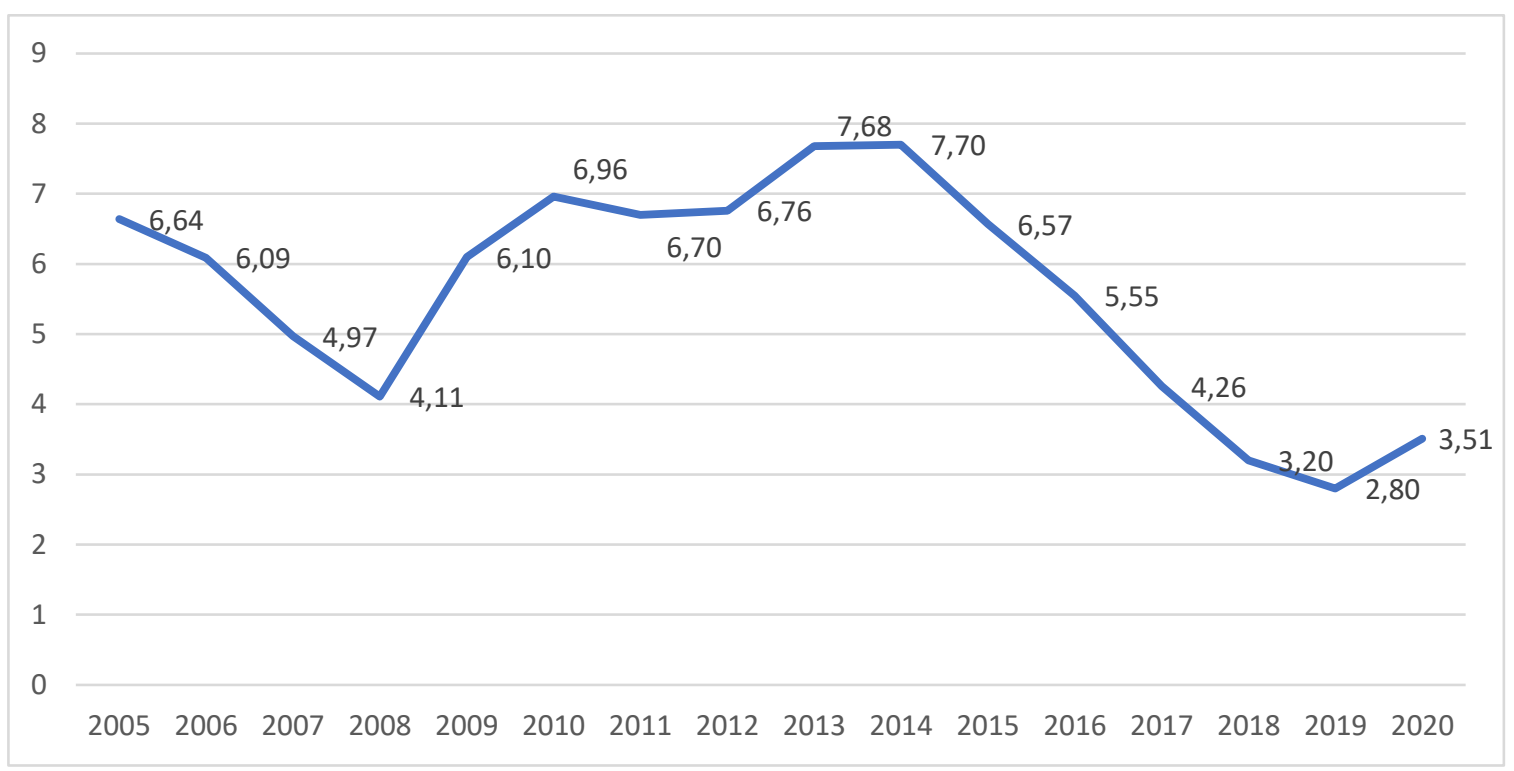

Figure 1. Share of unemployed persons as a percentage in the Czech Republic. Source: own processing based on (Český statistický úřad, 2021a)

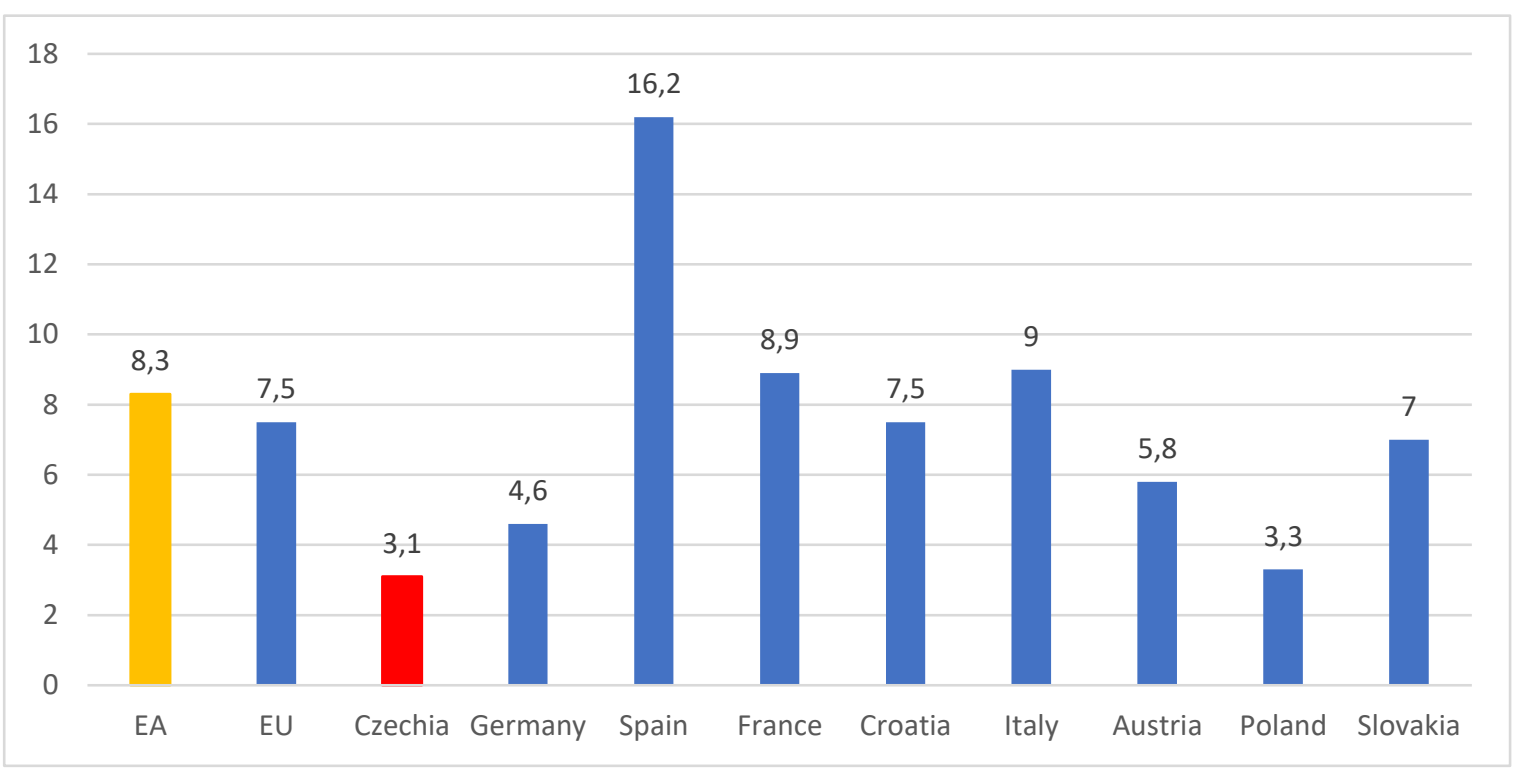

Figure 2. Seasonally adjusted unemployment in \% in December 2020, totals. Source: own processing based on (Eurostat, 2021)

In the 3rd quarter of 2020, the average gross monthly nominal wage per recalculated number of employees in the national economy increased by $5.1 \%$ compared to the same period of the previous year, it increased by $1.7 \%$ in real terms. The nominal wage was CZK 35,402 (see Figure 4). The median wage was CZK 31,183 (Český statistický úřad, 2021b). Figure 3 shows that in the third quarter increased the number of employees and also the growth of nominal wages (see Figure 4). 


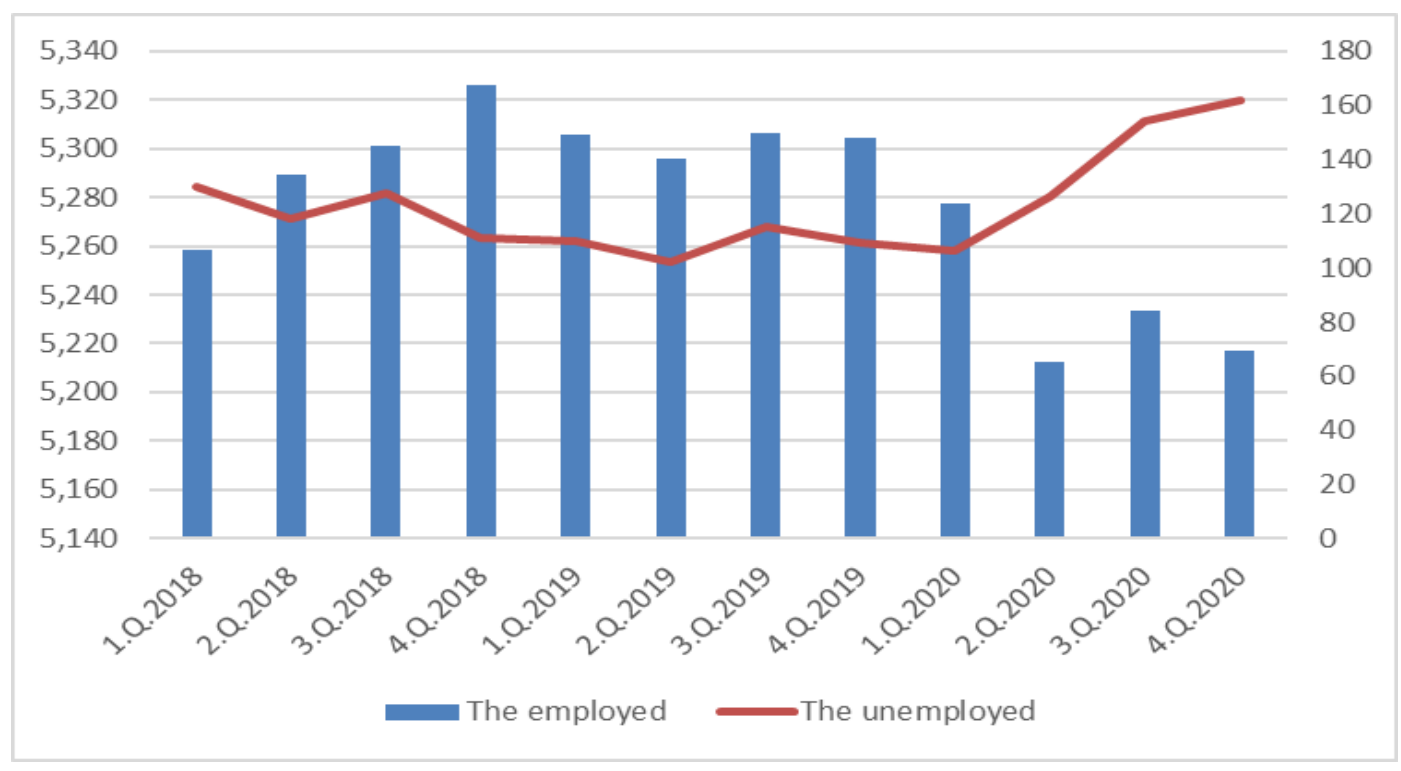

Figure 3. The employed and the unemployed in the Czech Republic. Source: own processing based on (Český statstický úřad, 2021)

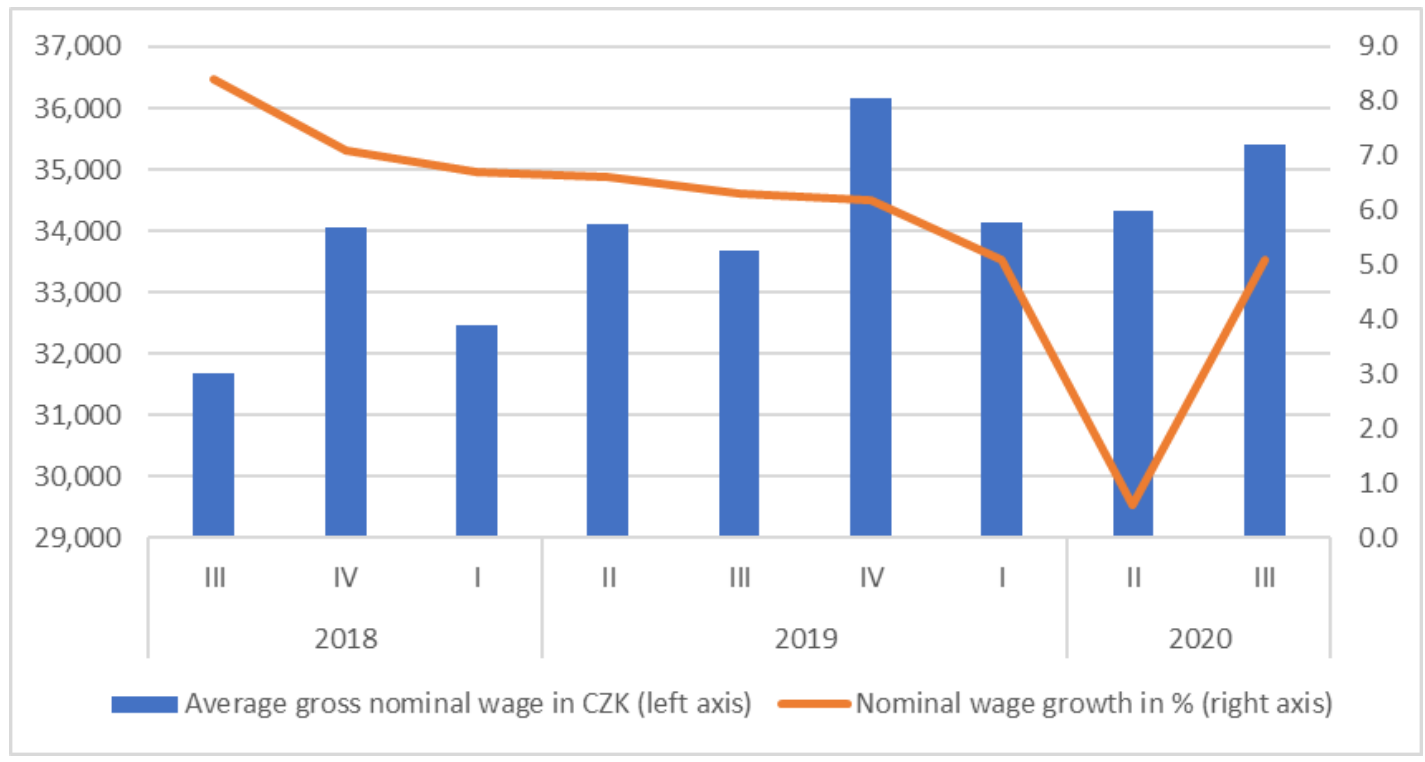

Figure 4. Average monthly wage - quarterly data (absolute numbers and year-on-year changes). Source: own processing based on (Český statistický úřad, 2021b)

3.1. Development of Employment and Unemployment in the Fourth Quarter of 2020 in the Czech Republic

Total employment decreased by 87.5 thousand year-on-year. Persons and reached 5,217.2 thousand persons in the 4 th quarter of 2020 . This is a decrease of $1.6 \%$. According to the methodology of the International Labor Organization (ILO), the number of unemployed increased by 52.5 thousand people. There was an increase in the number of economically inactive by 49.8 thousand (Český statstický úřad, 2021).

The number of unemployed women increased more than the number of unemployed men (ratio of 55.5 thousand women compared to 32.0 thousand men). At the same time, the total number of entrepreneurs (self-employed) decreased by 1.3 thousand. The decrease in 
the number of entrepreneurs with employees (employers) by 7.6 thousand is negative. It is positive that the number of entrepreneurs without employees increased by 6.3 thousand (Český statstický úřad, 2021).

According to the Czech Statistical Office (Český statstický úřad, 2021), which has been conducting a Labour Force Survey since April 2020 on issues related to the impact of the coronavirus crisis on the labour market. The results for the 4th quarter of 2020 show that the economic impact of unemployment on the household is considered by the vast majority of newly unemployed persons to be temporary and manageable. Compared to the 2nd quarter of the same year, $12.4 \%$ of respondents (by 4.4 pp less) experienced serious impacts and household insolvency, $34.0 \%$ of respondents (difficult by $7.1 \mathrm{pp}$ ) perceived heavy but manageable economic impacts, and $53.6 \%$ of respondents consider the temporary and manageable effects of a pandemic crisis (by 11.4 pp more).

Economic measures to support maintaining employment adopted by the Government of the Czech Republic during a pandemic Covid-19 (Vláda České republiky, 2020):

The Government of the Czech Republic has prepared a new package of programs to help affected segments and extended the validity of some measures that were already in force during the spring crisis:

- Tax relief

- Support for maintaining employment

- Support for innovative companies in connection with a pandemic

- Entrepreneurship support (culture, sports, bus, rent)

- Measures for employees

The Antivirus Employment Support Program, which is designed to help companies protect jobs and compensate employers for a significant portion of labour costs when their economic activity has been threatened by the spread of COVID-19, has been extended by a government decision. Antivirus A (now Antivirus Plus) until 31 December 2020, Antivirus B is still valid until 31 October 2020.

- The Antivirus A (Plus) program applies to companies for which there has been a forced restriction of operations on the basis of a government crisis measure or a regulation of hygiene quarantine (obstacles to work on the part of the employer or employee).

- Retroactively from 1 October, in the case of establishments that had to be completely closed, the state will pay employers 100 percent of the super-gross wage up to CZK 50,000 per employee.

- In the case of a quarantined employee, compensation remains at 80 percent per employee.

- Antivirus B applies to companies whose employees have had a barrier to work on the part of their employer due to economic difficulties related to the consequences of the spread of coronavirus.

- The Antivirus C program applies to companies with up to 50 employees and consists of the waiver of social security contributions for June, July, and August 2020, whereby the 
employer must meet the conditions for maintaining employment and maintaining salaries and pay employee premiums on time.

- The COVID 19 Technology Program supports projects that are directly related to combating the further spread of coronavirus through the acquisition of new technological devices and equipment, (the subsidy can reach up to 20 million crowns; in total, at least 300 million crowns are available). It is a program supporting innovative companies in connection with a pandemic.

The most important measures for employees include the approval of a crisis nursing home and the extension of the validity of the certificate.

\subsection{Changes in the Labour Market}

The changes in the labour market will be based on research by ManpowerGroup (Hovorková, 2020):

- Managers should understand the needs of each employee to avoid unsubstantiated assumptions and subconscious prejudices when evaluating employee performance.

- The skills needed will be constantly changing. Therefore, companies should support employees in training and acquiring new skills, and support distance learning so that employees' knowledge corresponds to the ever-changing needs of the company.

- Teleworking is not the only way to provide employees with more work flexibility and better work-life balance. For positions where a presence in the workplace is required, companies can offer their employees the opportunity to determine the beginning and end of working hours and more flexible work planning.

- The Covid-19 pandemic evokes feelings of isolation, stress, fear and anxiety and also leads to reflection on the value of health, well-being, family. Emotional well-being should be given the same emphasis as physical or organizational measures.

- At a time when stress is increasing and the biggest fear of employees is that they will lose their jobs, it is important to have good guidance at a distance, clear communication, a culture that allows you to combine work at work and from home.

- There may be a reduction in working hours for which companies should already be preparing.

- Pay more attention to the Industry 4.0 concept and gain a competitive advantage from it.

- Due to the pandemic, flexible forms of work (especially teleworking and teleworking) will be increasingly promoted. This flexibility has its pitfalls, especially in the form of casualization of the workforce - in the Czech Republic has the flexibility often form very precarious temporary contracts, employment agreement, contract of employment or even Svarc system. (Sociologický ústav \& Akademie věd ČR, v.v.i., 2021)

- The concept of Industry 4.0 and the related substitution of labour by capital will be further promoted. Companies that invest in new technologies and automated robotic lines will gain a competitive advantage.

- The labour market will change due to the Industry 4.0 concept. Some jobs will disappear, but others will be created. 
- Due to the Industry 4.0 concept, the average wage will increase as the demands on a skilled workforce increase.

- There will be an emphasis on lifelong learning for workers.

- By substituting labour for capital, the unemployment rate may rise.

- Demands for the growth of leisure time will increase. Even due to the concept of Industry 4.0, working hours can be reduced.

- Differences in unemployment rates between men and women may widen. Gender differences in the average wage may also persist.

\section{Discussion}

COVID-19 and blocking measures can affect gender inequality in the employment of women. A pandemic may not only be reflected in current changes in the labor market, but also in a change in gender roles in households as a result of changes in the division of labor, as Reichelt et al. (2020) point out. The question for discussion is whether the differences in employment and the average wage for individual sexes will deepen further. Women are currently disadvantaged, for example, by caring for children who have online tuition and, according to the Statistical Office of the Czech Republic, women are more in nursing care. This means lower incomes and a higher probability of losing a job.

Although the coronavirus (COVID-19) pandemic appears to disproportionately affect those in informal employment, they often receive less government support than the formally employed. This has short-term and long-term economic implications. The COVID-19 pandemic can accelerate current trends and force new solutions to better protect basic occupational safety while helping companies remain competitive. Of particular importance are government policies that promote job security, income security, steps to formalize employment, and justice for informal employees (Webb et al., 2020).

\section{Conclusions}

In advance, the impact of a pandemic on both labour supply and demand will be large, and an appropriate labour market policy can help revitalize the team by adapting quickly and effectively to the changing labour market (Lemieux et al., 2020).

The average number of hours worked per week decreased by 3.6 hours year-on-year to 31.6 hours in the Czech Republic due to Covid-19 (Český statstický úřad, 2021).

The current situation can contribute to greater availability of flexible forms of employment, especially teleworking, the often-mentioned home-office and the digitization of work. The fact that companies and organizations are currently being pushed to provide adequate technical equipment and to put in place internal policies that allow for more flexible forms of work, including more frequent work from home, could facilitate the combination of care and work in the future and thus have a positive impact on the situation of employed women, who combine work and care more often than men (Sociologický ústav \& Akademie věd ČR, v.v.i., 2021).

The concept of Industry 4.0, which is focused on robotics and production automation, is now gaining in importance. By using new automated robotic lines and ICT, companies can 
achieve higher productivity and efficiency. In the long run, they can achieve economic growth and a higher market share. Štěpán Jurajda from CERGE-EI (Svaz průmyslu a dopravy České republiky, 2020) stated that: "Long-term research, for example from Germany, shows us that companies that implement Industry 4.0 do not lay off their employees. But on the contrary, companies that do not introduce these technologies are gradually losing their position in the market and losing employees. "The analysis also showed that employees in companies that have invested in robotics, automation, or use artificial intelligence make more money than people in companies where they use these technologies in less or not at all.

The further development of employment and the average wage will be based on the further development of the Covid-19 pandemic. At this time, it is not possible to predict further developments. It will also be important how the end of the state employment support program Antivirus, which has not lost thousands of jobs, will affect the labour market.

Acknowledgments: „The work was supported by the internal project “SPEV - Economic Impacts under the Industry 4.0 / Society 5.0 Concept ", 2021, University of Hradec Králové, Faculty of Informatics and Management, Czech Republic“. The authors thank Martin Král for help with preparing this paper.

\section{References}

Bogoviz, A. V., Osipov, V. S., Chistyakova, M. K., \& Borisov, M. Y. (2019). Comparative Analysis of Formation of Industry 4.0 in Developed and Developing Countries. In E. G. Popkova, Y. V. Ragulina, \& A. V. Bogoviz (Eds.), Industry 4.0: Industrial Revolution of the 21st Century (Vol. 169, pp. 155-164). Springer International Publishing. https://doi.org/10.1007/978-3-319-94310-7_15

Český statistický úřad. (2021a). Hlavní makroekonomické ukazatele. https://www.czso.cz/csu/czso/hmu_cr

Český statistický úřad. (2021b). Prưměrné mzdy-3. Čtvrtletí 2020. https://www.czso.cz/csu/czso/cri/prumernemzdy-3-ctvrtleti-2020

Český statstický úřad. (2021). Zaměstnanost a nezaměstnanost podle výsledků VŠPS - 4. Čtortletí 2020. https://www.czso.cz/csu/czso/cri/zamestnanost-a-nezamestnanost-podle-vysledku-vsps-4-ctvrtleti-2020

Eurostat. (2021). Unemployment statistics. https://ec.europa.eu/eurostat/statisticsexplained/index.php/Unemployment_statistics

Hedvicakova, M. (2018). Unemployment and effects of the first work experience of university graduates on their idea of a job. Applied Economics, 50(31), 3357-3363. https://doi.org/10.1080/00036846.2017.1420895

Hedvičáková, M., \& Král, M. (2019). Benefits of KPIs for Industry Sector Evaluation: The Case Study from the Czech Republic. EEM Ekonomie a Management, 22(2), 97-113. https://doi.org/10.15240/tul/001/2019-2-007

Hovorková, K. (2020). Lidé chtějí po pandemii pracovat jinak. To tu od války nebylo, říká personalistka. ManpowerGroup. https://zpravy.aktualne.cz/finance/lide-chteji-po-pandemii-pracovat-jinak-to-tu-odvalky-nebylo/r ddefd520f2a311ea8972ac1f6b220ee8/?utm_source=www.seznam.cz\&utm_medium=sekcez-internetu\#dop_source_zone_name=hpfeed.sznhp.lptag\&dop_ab_variant=null

Kozubíková, Z. (2016, September). The 4th industrial revolution: A challenge for the education system. In International Conference on Informatization of Economic and Management Processes.

Král, M., \& Hájek, L. (2018). Analysis of Parliamentary Elections Costs in the Czech Republic. In P. Maresova, P. Jedlicka, \& I. Soukal (Eds.), Hradec Economic Days (pp. 472-481). https://doi.org/10.36689/uhk/hed/2018-01-046

Kucharčíková, A., Tokarčíková, E., \& Ďurišová, M. (2015). Human capital efficiency in trading company. In The 9th International Days of Statistics and Economics. Conference Proceedings, 2015 (pp. 892-901). https://msed.vse.cz/msed_2015/sbornik/front.html

Lee, S., Schmidt-Klau, D., \& Verick, S. (2020). The Labour Market Impacts of the COVID-19: A Global Perspective. The Indian Journal of Labour Economics, 63(S1), 11-15. https://doi.org/10.1007/s41027-020-00249-y

Lemieux, T., Milligan, K., Schirle, T., \& Skuterud, M. (2020). Initial Impacts of the COVID-19 Pandemic on the Canadian Labour Market. Canadian Public Policy, 46(s1), S55-S65. https://doi.org/10.3138/cpp.2020-049

Maresova, P., Soukal, I., Svobodova, L., Hedvicakova, M., Javanmardi, E., Selamat, A., \& Krejcar, O. (2018). Consequences of Industry 4.0 in Business and Economics. Economies, 6(3), 46. https://doi.org/10.3390/economies6030046 
Matějíček, M., \& Marešová, P. (2020). Open Business Model and Open Innovation: Bibliographic Analysis. In P. Maresova, P. Jedlicka, K. Firlej, \& I. Soukal (Eds.), Hradec Economic Days (pp. 515-526). https://doi.org/10.36689/uhk/hed/2020-01-059

Ragulina, Y. V. (2019). Priorities of Development of Industry 4.0 in Modern Economic Systems with Different Progress in Formation of Knowledge Economy. In E. G. Popkova, Y. V. Ragulina, \& A. V. Bogoviz (Eds.), Industry 4.0: Industrial Revolution of the 21st Century (Vol. 169, pp. 167-174). Springer International Publishing. https://doi.org/10.1007/978-3-319-94310-7_16

Reichelt, M., Makovi, K., \& Sargsyan, A. (2020). The impact of COVID-19 on gender inequality in the labor market and gender-role attitudes. European Societies, 1-18. https://doi.org/10.1080/14616696.2020.1823010

Sakshaug, J. W., Beste, J., Coban, M., Fendel, T., Haas, G.-C., Hülle, S., Kosyakova, Y., König, C., Kreuter, F., Küfner, B., Müller, B., Osiander, C., Schwanhäuser, S., Stephan, G., Vallizadeh, E., Volkert, M., Wenzig, C., Westermeier, C., Zabel, C., \& Zins, S. (2020). Impacts of the COVID-19 Pandemic on Labor Market Surveys at the German Institute for Employment Research. Survey Research Methods, 229-233. https://doi.org/10.18148/SRM/2020.V14I2.7743

Sociologický ústav \& Akademie věd ČR, v.v.i. (2021). Dopady opatření proti pandemii na ženy a muže na trhu práce. https://www.soc.cas.cz/aktualita/dopady-opatreni-proti-pandemii-na-zeny-muze-na-trhu-prace

Sozinova, A. A. (2019). Causal Connections of Formation of Industry 4.0 from the Positions of the Global Economy. In E. G. Popkova, Y. V. Ragulina, \& A. V. Bogoviz (Eds.), Industry 4.0: Industrial Revolution of the 21st Century (Vol. 169, pp. 131-143). Springer International Publishing. https://doi.org/10.1007/978-3-31994310-7_13

Svaz průmyslu a dopravy České republiky. (2020). Trendy na trhu práce: Průmysl 4.0 zvýší produktivitu i mzdy. https:/www.spcr.cz/projekty/probihajici-projekty/14170-trendy-na-trhu-prace-prumysl-4-0-zvysiproduktivitu-i-mzdy

Svobodová, L., \& Hedvičáková, M. (2015). Doing Business in the Countries of Visegrad Group. Procedia Economics and Finance, 34, 453-460. https://doi.org/10.1016/S2212-5671(15)01654-8

van Barneveld, K., Quinlan, M., Kriesler, P., Junor, A., Baum, F., Chowdhury, A., Junankar, P. (Raja), Clibborn, S., Flanagan, F., Wright, C. F., Friel, S., Halevi, J., \& Rainnie, A. (2020). The COVID-19 pandemic: Lessons on building more equal and sustainable societies. The Economic and Labour Relations Review, 31(2), $133-157$. https://doi.org/10.1177/1035304620927107

Vláda České republiky. (2020). Podpora a úlevy pro podnikatele a zaměstnance. https://www.vlada.cz/cz/mediacentrum/aktualne/podpora-a-ulevy-pro-podnikatele-a-zamestnance-180601/

Webb, A., McQuaid, R., \& Rand, S. (2020). Employment in the informal economy: Implications of the COVID-19 pandemic. International Journal of Sociology and Social Policy, 40(9/10), 1005-1019.

https://doi.org/10.1108/IJSSP-08-2020-0371 